\title{
Erratum: The impact of a Biblical Fatherhood Programme for faith communities in the Christiana district: A reflective and community engagement strategy
}

Author:

Fazel E. Freeks ${ }^{1}$ (D)

\section{Affiliation:}

${ }^{1}$ Unit for Reformed Theology and the Development of the South African Society, Faculty of Theology, North-West University, Potchefstroom, South Africa

Corresponding author:

Fazel Freeks,

10589686@nwu.ac.za

Date:

Published: 23 Nov. 2021

How to cite this article: Freeks, F.E., 2021, 'Erratum: The impact of a Biblical Fatherhood Programme for faith communities in the Christiana district: A reflective and community engagement strategy', In die Skriflig 55(3), a2794. https://doi.org/ 10.4102/ids.v55i3.2794

\section{Copyright:}

(C) 2021. The Authors. Licensee: AOSIS. This work

is licensed under the Creative Commons Attribution License.
In the version of this article initially published, Freeks, F.E., 2021, 'The impact of a Biblical Fatherhood Programme for faith communities in the Christiana district: A reflective and community engagement strategy', In die Skriflig 55(1), a2680. https://doi.org/10.4102/ids. v55i1.2680, the article issue number was given incorrectly. The correct issue number should be number 3 instead of number 1 .

This correction does not alter the study's findings of significance or overall interpretation of the study results. The publisher apologises for any inconvenience caused. 